\title{
The Dietary Supplemental Effect of Nitroethanol in Comparison with Monensin on Methane Emission, Growth Performance and Carcass Characteristics in Female Lambs
}

\author{
Zhen-Wei Zhang ${ }^{1,2}{ }^{\text {, Yan-Lu Wang }}{ }^{1}$, Yong-Yan Chen ${ }^{1}{ }^{1}$, Luo-Tong Zhang ${ }^{1}$, Ying-Jie Zhang ${ }^{3}$, Yue-Qin Liu ${ }^{3}$, \\ Yun-Xia Guo ${ }^{4}$ and Hong-Jian Yang $1, * \mathbb{B}$
}

check for updates

Citation: Zhang, Z.-W.; Wang, Y.-L.; Chen, Y.-Y.; Zhang, L.-T.; Zhang, Y.-J.; Liu, Y.-Q.; Guo, Y.-X.; Yang, H.-J. The Dietary Supplemental Effect of Nitroethanol in Comparison with Monensin on Methane Emission, Growth Performance and Carcass Characteristics in Female Lambs. Animals 2021, 11, 327. https:// doi.org/10.3390/ani11020327

Academic Editors: Giuseppe Martino and Teresa Manso

Received: 10 December 2020

Accepted: 19 January 2021

Published: 28 January 2021

Publisher's Note: MDPI stays neutral with regard to jurisdictional claims in published maps and institutional affiliations.

Copyright: (c) 2021 by the authors. Licensee MDPI, Basel, Switzerland. This article is an open access article distributed under the terms and conditions of the Creative Commons Attribution (CC BY) license (https:// creativecommons.org/licenses/by/ $4.0 /)$.
1 State Key Laboratory of Animal Nutrition, College of Animal Science and Technology, China Agricultural University, Beijing 100193, China; qingyibushuo@163.com (Z.-W.Z.); yanluwang@yeah.net (Y.-L.W.); yanz00@foxmail.com (Y.-Y.C.); zhangluotong@agri.gov.cn (L.-T.Z.)

2 Liaocheng Research Institute of Donkey High-Efficiency Breeding and Ecological Feeding, Liaocheng University, Liaocheng 252059, China

3 College of Animal Science and Technology, Hebei Agricultural University, Baoding 071000, China; zhangyingjie66@126.com (Y.-J.Z.); liuyueqin66@126.com (Y.-Q.L.)

4 College of Life Science, Hebei Agricultural University, Baoding 071000, China; gyx310@163.com

* Correspondence: yang_hongjian@cau.edu.cn

Simple Summary: The objective of present study was to determine the effects of 2-nitroethanol $(\mathrm{NEOH})$ in comparison with monensin on methane $\left(\mathrm{CH}_{4}\right)$ emission, growth performance and carcass characteristics in female lambs. Both monensin and $\mathrm{NEOH}$ are potent $\mathrm{CH}_{4}$ inhibitors that can reduce dietary energy loss. The average daily gain (ADG) and feed conversion rate were improved with monensin and $\mathrm{NEOH}$ addition, suggesting that $\mathrm{NEOH}$ in comparison with monensin presented a similarly lasting beneficial effect on feed efficiency for female lambs. In addition, monensin and $\mathrm{NEOH}$ increased the net muscle percentage to carcass weight $(p=0.03)$, and they caused a reduction in feed consumption and feed costs resulting in a higher net revenue and economic efficiency. In summary, $\mathrm{NEOH}$ in comparison with monensin presented a greater promoting effect on energy utilization in the female feedlotting lambs by inhibiting rumen methanogenesis more efficiently.

Abstract: This study was conducted to evaluate the dietary supplemental effects of 2-nitroethanol $(\mathrm{NEOH})$ in comparison with monensin on methane $\left(\mathrm{CH}_{4}\right)$ emission, growth performance and carcass characteristics in female lambs. Sixty female, small-tailed Chinese Han lambs ( $3.5 \pm 0.3$ month) were randomly allotted into three dietary treatment groups: (1) Control group, a basal control diet, (2) monensin group, the basal diet added with $40 \mathrm{mg} / \mathrm{kg}$ monensin, (3) NEOH group, the basal diet added with $277 \mathrm{mg} / \mathrm{kg}$ nitroethanol, and the feedlotting trial lasted for 70 days. Although dietary addition of monensin and NEOH did not affect nutrient digestibility of lambs, both monensin and $\mathrm{NEOH}$ decreased the calculated $\mathrm{CH}_{4}$ production $(12.7 \%$ vs. $17.4 \%$ decrease; $p<0.01)$. In addition, the $\mathrm{CH}_{4}$ production represents less dietary energy loss in the monensin and $\mathrm{NEOH}$ group than in the control, indicating that monensin and $\mathrm{NEOH}$ are potent $\mathrm{CH}_{4}$ inhibitors that can reduce dietary energy loss. Dietary addition of monensin and $\mathrm{NEOH}$ decreased dry matter intake $(p<0.01)$; however, they increased the ADG of female lambs $(p<0.01)$. As a result, both monensin and NEOH increased feed conversion efficiency of the feedlotting lambs $(p<0.01)$, suggesting that feed energy saved from $\mathrm{CH}_{4}$ production promoted the feed efficiency and ADG in the present study. Except for the fact that $\mathrm{NEOH}$ addition increased the net muscle percentage to carcass weight $(p=0.03)$, neither monensin nor NEOH had a significant influence on carcass characteristics of female lambs $(p>0.05)$. From an economic point of view, $\mathrm{NEOH}$ and monensin caused a reduction in feed consumption costs, therefore resulting in a higher net revenue and economic efficiency than the control. In summary, dietary supplementation of $\mathrm{NEOH}$ in comparison with monensin presented a more promoting effect on energy utilization in female lambs by inhibiting rumen methanogenesis more efficiently, and $\mathrm{NEOH}$ improved the net revenue and economic efficiency more significantly than monensin. 
Keywords: 2-nitroethanol; monensin; $\mathrm{CH}_{4}$ emission; growth performance; carcass characteristics

\section{Introduction}

Ruminant herbivores depend on microbial fermentation within the rumen to acquire energy from plant compounds. Rumen function has been strongly manipulated by supplementing the forage diets with readily fermentable carbohydrates and additives in order to improve animal productivity [1,2]. However, this type of feeding sometimes induces rumen dysfunction because of an imbalance in the microbial populations [2]. Dietary supplementation of yeast cultures has been reported to increase body weight gain and feed conversion efficiency in livestock [3].

Methane $\left(\mathrm{CH}_{4}\right)$ is an important greenhouse gas contributing to global warming $[4,5]$. Ruminants produce $\mathrm{CH}_{4}$ from fermentation, representing a loss of up to $12 \%$ of the feed energy [6,7]. A possible option to increase feed efficiency and hence ruminant productivity is to improve growth performance and feed conversion rate (FCR) of ruminant animals by decreasing ruminal $\mathrm{CH}_{4}$ production.

Monensin is a polyether ionophore that has been extensively used as a routine feed additive in ruminants to manipulate rumen fermentation to reduce methane production and increase feed efficiency [8]. Guan et al. [9] in an earlier study noted that monensin increased FCR by $6.3 \%$ in Angus yearling steers as a result of reducing the dry matter intake (DMI) without changing the average daily gain (ADG). Soltan et al. revealed that dietary supplementation of monensin in Barki lambs improved ADG and FCR by $25.2 \%$ and $29.2 \%$, respectively [10]. In addition, numerous studies have reported significant reduction (6.5-12\%) in $\mathrm{CH}_{4}$ emissions due to feeding monensin [11-13].

Several nitrocompounds, including nitroethane, 2-nitroethanol, 2-nitro-1-propanol and 3-nitro-1-propionic acid have been identified as reducing $\mathrm{CH}_{4}$ production both in vitro and in vivo [14-17]. Although some investigations have suggested that nitrocompounds such as nitroethane, 2-nitroethanol and 2-nitro-1-propanol do not have negative effects on ruminal fermentation or animal performance and the responses may differ depending on gender. In fact, a recent work by Zhang et al. compared the dietary addition effect of monensin and NEOH on ruminal methanogenesis and growth performance of male lambs [18], the latter one led to a greater improvement in ADG and FCR due to the lower $\mathrm{CH}_{4}$ production, but it is not clear if such a response could also occur in female lambs.

Previous studies illustrated that domestic farm animals differ in growth rate depending on their gender $[19,20]$. Abouheif et al. reported that the growth rate of Najdi ram lambs was higher than that of ewe lambs in the same age [21]. Aregheore also found that the males have a higher growth rate than females for the West African Dwarf goats [22]. However, the female lambs cannot be eliminated in feeding practice, especially in an intensive production system in China. How to improve the feed efficiency and animal performance of female lambs is also of great significance to increase the economic benefits for livestock producers. $\mathrm{CH}_{4}$ mitigation has the potential to improve feed energy efficiency; therefore, reducing $\mathrm{CH}_{4}$ production with $\mathrm{NEOH}$ and monensin may not only contribute to global efforts to reduce greenhouse gas emissions but could also improve the efficiency of feed conversion. In the present study, female lambs were served as experimental animals, and the objective was to evaluate the dietary supplemental effect of $\mathrm{NEOH}$ in comparison with monensin on nutrient digestibility, $\mathrm{CH}_{4}$ emission, growth performance and carcass characteristics as well as economic returns.

\section{Materials and Methods}

This study was approved by the Guidelines of the Beijing Municipal Council on Animal Care-Animal Production Ethics Committee (with protocol CAU20171014-1). 


\subsection{Chemicals}

The light-yellow liquid nitroethanol (90\% purity) was purchased from Beijing Lingrui Biotechnology Co., Ltd. (Beijing, China), and ionophore sodium monensin was purchased from Sigma Aldrich (St. Louis, Mo, USA).

\subsection{Experiment Design and Animals Feeding}

Sixty female, small-tailed Chinese Han lambs $(29.6 \pm 0.7 \mathrm{~kg} ; 3.5 \pm 0.3$ month) were randomly assigned to one of three treatments: (1) a basal control diet (Control), (2) the basal diet supplemented with $40 \mathrm{mg} / \mathrm{kg}$ sodium monensin (monensin), (3) the basal diet supplemented with $277 \mathrm{mg} / \mathrm{kg}$ 2-nitroethanol $(\mathrm{NEOH})$ on dry matter basis $(\mathrm{DM})$. The dosage level of monensin and NEOH was in accordance with the reference of Soltan et al. [10] and Anderson et al. [14]. Lambs were housed with four animals to a pen $(2 \mathrm{~m} \times 5 \mathrm{~m})$ with bamboo slatted floors. The pens were equipped with an individual feeding and watering troughs. All lambs were drenched against internal parasites and sprayed for ectoparasites prior to the experiment.

Diets were prepared as total mixed rations (TMR), which were formulated to meet their nutrient requirements ( $250 \mathrm{~g} /$ day) and growth requirements (Table 1). Lambs were adapted to their designated diet for 7 days before the experimental period. The whole feeding experiment consisted of the early stage (day 0-32) and later stage (day 33-70) of the fattening period. In order to avoid the adaptability of lambs to $\mathrm{CH}_{4}$ inhibitors, each stage included a treatment application period (day 0-16 and day 33-50) and a withdrawal of treatment period (day 17-32 and day 51-70). Sodium monensin and NEOH product were added in the treatment application period, while all three groups of lambs returned to be fed the same controlled diet in the withdrawal period. During the entire experiment, lambs had free access to water and mineral lick block.

Table 1. Ingredients and nutrient level of the total mixed ration (TMR) for feedlotting lambs.

\begin{tabular}{cc}
\hline Item & TMR \\
\hline Ingredients (g/kg, as fed basis) & 600 \\
Corn silage & 100 \\
Peanut vine hay & 109.5 \\
Corn meal & 30 \\
Wheat bran & 150 \\
Soybean meal & 3 \\
Limestone & 1.5 \\
Sodium bicarbonate & 3 \\
Salt & 3 \\
Premix 1 & \\
Crion (g/kg, as dry matter) & 944 \\
Crude protein (N $\times 6.25)$ & 163 \\
Ether extract & 22 \\
Neutral detergent fiber & 360 \\
Acid detergent fiber & 223 \\
Calcium & 5.5 \\
Phosphorus & 4.5 \\
Gross Energy (MJ/kg) & 15.2 \\
\hline
\end{tabular}

${ }^{1}$ The mineral-vitamin premix provided nutrients per kg of diet: $\mathrm{Mn}, 64 \mathrm{mg}$; Fe, $56 \mathrm{mg}$; Zn, $45 \mathrm{mg}$; Cu, $9.6 \mathrm{mg}$; Se, $0.3 \mathrm{mg}$; I, $1 \mathrm{mg}$; vitamin A, 48,000 IU; vitamin D, 11,000 IU; vitamin E, $33 \mathrm{IU}$; folic acid, $1.0 \mathrm{mg}$; nicotinic acid, $60 \mathrm{mg}$; d-calpanate, $30 \mathrm{mg}$ and d-biotin.

\subsection{Sampling and Measurements}

The feed TMR was offered to lambs at 08:00 and 17:00. The amount of fresh TMR offered was adjusted according to feed intake of the previous day to ensure a $10 \%$ refusal. The feed offered and refused was weighted daily at per pen level, and samples were collected and ground through $1 \mathrm{~mm}$ screen, for subsequent analyses of DM. Dry matter 
intake (DMI) was calculated daily as the difference in dry matter between feed offered and the refusal. Live body weight of lambs was recorded before morning feeding, twice at the beginning and at the end of the experiment, respectively, and once every two weeks. Mean daily gain was calculated by the difference between two consecutive weightings. Feed conversion rate (FCR) was calculated as ADG divided by DMI every two weeks. Feed efficiency (FCR) was expressed as body weight gain per unit of feed consumption.

Feces samples of each animal were collected for 3 consecutive days in the morning at the end of each phase via grab sampling through rectal palpation. Feces samples were checked for gastrointestinal parasites by coprological analysis. Then, feces for the collection period were combined for each lamb and oven-dried at $65^{\circ} \mathrm{C}$ over a four-day period. Dried feces were then pooled equally within pen for chemical analysis.

At the end of the experiment (day 70), 15 lambs from each treatment diet were randomly selected and their live body weight was recorded after fasting for $18 \mathrm{~h}$. Lambs were then slaughtered by exsanguination using conventional humane procedures. Firstly, lambs were knocked unconscious using electroarcosis of $220 \mathrm{~V}$ for $15 \mathrm{~s}$. After bleeding, head, feet and skin were removed, and the carcasses were eviscerated. Their heart, liver, spleen, lungs, kidneys, digestive tract and the kidney-pelvic-gut fat were completely removed. The carcasses were subsequently weighed and chilled at $4{ }^{\circ} \mathrm{C}$ for $24 \mathrm{~h}$. Then, carcasses were sawed into two symmetrical sides along backbone. After cutting the right side carcasses between the 12th and 13th ribs, the area of the longissimus dorsi was traced onto paper and the area was measured by computer scanning. The backfat thickness of the left side carcasses was determined over the deepest part of the loin-eye muscle. At last, the carcasses were separated and the net meat and bone were weighed. Dressing percentage was calculated as a ratio of fasting weight to carcass weight. Net meat percentage was calculated as a ratio of net meat weight to carcass weight.

\subsection{Chemical Analyses}

Samples of the consumed TMR, refusals and fecal matter were dried in a forced-air oven at $65{ }^{\circ} \mathrm{C}$ for $48 \mathrm{~h}$ and then ground to pass through a $1 \mathrm{~mm}$ screen. Following the procedures of AOAC (Association of Official Analytical Chemists, Gaithersburg, MD, USA), dry matter (DM; method ID 934.01), ash (method ID 942.05), crude protein (CP, method ID 976.06) and ether extract (EE, method ID 960.39) were analyzed [23]. According to the method of Van Soest et al. [24], neutral detergent fiber (aNDF) was determined with heat stable $\alpha$-amylase and sodium sulfite addition and expressed inclusive of residual ash. Acid detergent fiber (ADF) were expressed inclusive of residual ash. Gross energy of diets and fecal samples were determined in an oxygen bomb calorimeter (MTZW-4, Shanghai Mitong Electromechanical Technology Co., Ltd., Shanghai, China).

\subsection{Calculations}

Body weight of each lamb $(\mathrm{kg})$ at different feeding days (BWd) was fitted to a linear model Equation (1):

$$
\mathrm{BW}_{d}=i \mathrm{BW}_{0}+k \times \text { day }
$$

where $\mathrm{BW}_{d}$ is the body weight of lambs at $\mathrm{dth}$ feeding day; $i \mathrm{BW}_{0}$ is the initial body weight of lambs at day $=0 ; k$ is the coefficient factor ( $\mathrm{kg} /$ day, ADG) in the linear model.

Nutrient digestibility was estimated by the indigestible acid insoluble ash (AIA) in diet and feces samples [25]. It was calculated as Equation (2):

$$
\text { Nutrient digestibility, } \%=\left[1-\left(\mathrm{N}_{\mathrm{f}} \times \mathrm{D}_{\mathrm{AIA}}\right) /\left(\mathrm{N}_{d} \times \mathrm{F}_{\mathrm{AIA}}\right)\right] \times 100 \%
$$

where, $\mathrm{N}_{\mathrm{d}}$ and $\mathrm{N}_{\mathrm{f}}$ is the nutrient concentration in diets and feces samples, respectively; $\mathrm{D}_{\mathrm{AIA}}$ and $\mathrm{F}_{\mathrm{AIA}}$ is the AIA concentration in diets and feces samples, respectively. 
Gross energy intake (GEI), digestible energy (DE), metabolic energy (ME) and $\mathrm{CH}_{4}$ energy $\left(\mathrm{CH}_{4} \mathrm{E}\right)[26]$ was calculated as Equations (3)-(6):

$$
\begin{aligned}
& \text { GEI, MJ / d = gross energy } \times \text { DMI; } \\
& \mathrm{DE}, \mathrm{MJ} / \mathrm{d}=\mathrm{GE} \text { digestibility } \times \mathrm{GEI} ; \\
& \mathrm{ME}, \mathrm{MJ} / \mathrm{d}=0.82 \times \mathrm{DE} ; \\
& \mathrm{CH}_{4} \mathrm{E}, \mathrm{MJ} / \mathrm{d}=0.208+0.049 \times \mathrm{GEI} ;
\end{aligned}
$$

\subsection{Statistical Analysis}

Data were subjected to ANOVA using the General Linear Model (GLM) procedure of SAS in which monensin and NEOH treatment was included as fixed effect. Least square means and standard errors of means were determined by LSMEANS procedure of the SAS. Tukey's test was used for means comparison. Significance was declared at a level of $p<0.05$ and a trend towards significance at $p \leq 0.10$.

\section{Results}

\subsection{Digestibility}

Dietary addition of monensin and NEOH did not affect digestibility of DM, OM, CP,

\begin{tabular}{|c|c|c|c|c|c|}
\hline \multicolumn{6}{|c|}{ Treatment } \\
\hline Item & Control & Monensin & NEOH & SEM & $p$ Value \\
\hline \multicolumn{6}{|c|}{ Dry matter digestibility, $\mathrm{g} / \mathrm{kg}$} \\
\hline day $0 \sim 32$ & 715 & 712 & 711 & 5.4 & 0.82 \\
\hline day $33 \sim 70$ & 703 & 706 & 695 & 11.4 & 0.76 \\
\hline \multicolumn{6}{|c|}{ Organic matter digestibility, $\mathrm{g} / \mathrm{kg}$} \\
\hline day $0 \sim 32$ & 737 & 733 & 731 & 5.1 & 0.72 \\
\hline day $33 \sim 70$ & 723 & 729 & 714 & 11.1 & 0.63 \\
\hline \multicolumn{6}{|c|}{ Crude protein digestibility, $\mathrm{g} / \mathrm{kg}$} \\
\hline day $0 \sim 32$ & 712 & 718 & 714 & 5.9 & 0.76 \\
\hline day $33 \sim 70$ & 656 & 677 & 668 & 12.6 & 0.50 \\
\hline \multicolumn{6}{|c|}{ Neutral detergent fibre digestibility, $\mathrm{g} / \mathrm{kg}$} \\
\hline day $0 \sim 32$ & 577 & 563 & 552 & 8.7 & 0.19 \\
\hline day $33 \sim 70$ & 560 & 543 & 482 & 30.3 & 0.23 \\
\hline \multicolumn{6}{|c|}{ Acid detergent fibre digestibility, $\mathrm{g} / \mathrm{kg}$} \\
\hline day $0 \sim 32$ & 558 & 567 & 541 & 22.0 & 0.72 \\
\hline day $33 \sim 70$ & 552 & 570 & 561 & 37.8 & 0.94 \\
\hline
\end{tabular}
NDF and ADF of lambs ( $p>0.05$; Table 2).

Table 2. Dietary supplemental effects of monensin $(40 \mathrm{mg} / \mathrm{kg}$.DM) and 2-nitroethanol (NEOH, $277 \mathrm{mg} / \mathrm{kg} \cdot \mathrm{DM}$ ) on total tract apparent digestibility of female lambs.

SEM, standard error of the mean.

\subsection{Growth Performance}

The body weight (BW) of feedlotting lambs at different feeding periods was fitted to a linear model (Figure 1). The growth rate was greater in both monensin and NEOH group than in control group, and they ranked: $\mathrm{NEOH}>$ monensin $>$ Control.

Dietary addition of monensin and NEOH decreased DMI (Table 3; $p<0.01$ ); however, both monensin and NEOH increased ADG of female lambs $(p<0.01)$. As a result, the FCR of lambs was promoted by monensin and NEOH addition $(p<0.01)$. 


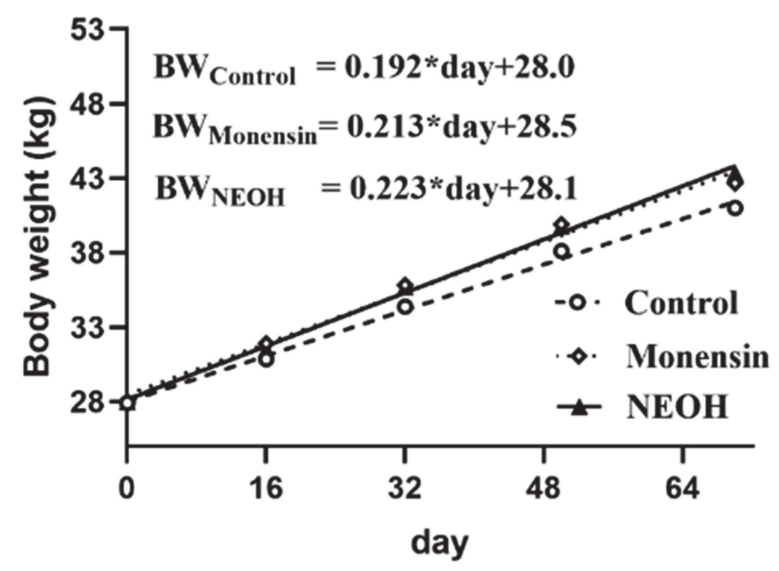

Figure 1. Dietary supplemental effects of monensin (40 mg/ $\mathrm{kg} \cdot \mathrm{DM})$ and 2-nitroethanol (NEOH, $277 \mathrm{mg} / \mathrm{kg} \cdot \mathrm{DM})$ on live body weight $(\mathrm{BW})$ of female lambs.

Table 3. Dietary supplemental effects of monensin (40 mg/ kg.DM) and 2-nitroethanol (NEOH, $277 \mathrm{mg} / \mathrm{kg} \cdot \mathrm{DM}$ ) on growth performance of female lambs.

\begin{tabular}{cccccc}
\hline & \multicolumn{3}{c}{ Treatment } & & \\
\hline Items & Control & Monensin & NEOH & SEM & $p$ Value \\
\hline Dry matter intake (kg/day) & $1045^{\mathrm{a}}$ & $998^{\mathrm{b}}$ & $1006^{\mathrm{b}}$ & 7.000 & $<0.01$ \\
Average daily gain (g/day) & $186^{\mathrm{b}}$ & $213^{\mathrm{a}}$ & $218^{\mathrm{a}}$ & 2.000 & $<0.01$ \\
Feed conversion ration & $0.18^{\mathrm{b}}$ & $0.21^{\mathrm{a}}$ & $0.22^{\mathrm{a}}$ & 0.003 & $<0.01$ \\
\hline
\end{tabular}

Means within a row with different letters differ $(p<0.05)$. SEM, standard error of the mean; feed conversion ration calculated as average daily gain divided by dry matter intake.

\subsection{Methane Emission}

Both monensin and NEOH addition decreased the gross energy intake (GEI), digestible energy (DE), metabolizable energy (ME), and fecal energy loss of female lambs (Table 4; $p<0.01$ ). Methane emission of fattening lambs was estimated based on DMI, GEI and DEI, and dietary addition of monensin and $\mathrm{NEOH}$ decreased $\mathrm{CH}_{4}$ emission $\left(\mathrm{CH}_{4} \mathrm{DMI}, \mathrm{CH}_{4} \mathrm{GEI}\right.$ and $\mathrm{CH}_{4 \mathrm{DEI}} ; p<0.01$ ) as well as methane emission per kg ADG (up to $-12.7 \%$ vs. $-17.4 \%$ decrease; $p<0.01$ ). In addition, the $\mathrm{NEOH}$ in comparison with monensin exhibits greater inhibition on the $\mathrm{CH}_{4}$ energy $\left(\mathrm{CH}_{4} \mathrm{E} ; p<0.01\right)$. The ration of $\mathrm{CH}_{4} \mathrm{E}$ to $\mathrm{GE}$ in three groups ranked as NEOH (5.8) < monensin (6.0) < Control (6.3), and both monensin and NEOH decreased the ration of $\mathrm{CH}_{4} \mathrm{E}$ to $\mathrm{DE}$ and $\mathrm{ME}$.

Table 4. Dietary supplemental effects of monensin $(40 \mathrm{mg} / \mathrm{kg}$.DM) and 2-nitroethanol (NEOH, $277 \mathrm{mg} / \mathrm{kg}$. DM) on methane emission of female lambs.

\begin{tabular}{cccccc}
\hline & \multicolumn{5}{c}{ Treatment } \\
\hline Items & Control & Monensin & NEOH & SEM & $p$-Value \\
\hline Gross energy intake (MJ/day) & $15.3^{\mathrm{a}}$ & $14.6^{\mathrm{c}}$ & $14.8^{\mathrm{b}}$ & 0.05 & $<0.01$ \\
Fecal energy loss (MJ/day) & $4.8^{\mathrm{a}}$ & $4.6^{\mathrm{b}}$ & $4.7^{\mathrm{b}}$ & 0.04 & $<0.01$ \\
Digestible energy (MJ/day) & $10.6^{\mathrm{a}}$ & $10.3^{\mathrm{b}}$ & $10.3^{\mathrm{b}}$ & 0.03 & $<0.01$ \\
Metabolizable energy (MJ/day) & $8.7^{\mathrm{a}}$ & $8.5^{\mathrm{b}}$ & $8.4^{\mathrm{b}}$ & 0.02 & $<0.01$ \\
$\mathrm{CH}_{4}$ (L/day) & $12.3^{\mathrm{a}}$ & $11.3^{\mathrm{b}}$ & $11.0^{\mathrm{c}}$ & 0.03 & $<0.01$ \\
$\mathrm{CH}_{4}$ (L/kg ADG) & $70.0^{\mathrm{a}}$ & $61.1^{\mathrm{b}}$ & $57.8^{\mathrm{c}}$ & 0.80 & $<0.01$ \\
$\mathrm{CH}_{4}$ DMI (L/day) & $11.4^{\mathrm{a}}$ & $11.1^{\mathrm{b}}$ & $11.1^{\mathrm{b}}$ & 0.02 & $<0.01$ \\
$\mathrm{CH}_{4}$ DEI (L/day) & $12.8^{\mathrm{a}}$ & $12.6^{\mathrm{b}}$ & $12.5^{\mathrm{b}}$ & 0.02 & $<0.01$ \\
$\mathrm{CH}_{4} \mathrm{E}\left(\mathrm{CH} \mathrm{CH}_{4}\right.$ energy, MJ/day) & $0.96^{\mathrm{a}}$ & $0.88^{\mathrm{b}}$ & $0.86^{\mathrm{c}}$ & 0.002 & $<0.01$ \\
$\mathrm{CH}_{4} \mathrm{E}$ in Gross energy (\%) & $6.3^{\mathrm{a}}$ & $6.0^{\mathrm{b}}$ & $5.8^{\mathrm{c}}$ & 0.01 & $<0.01$ \\
$\mathrm{CH}_{4} \mathrm{E}$ in Digestible energy (\%) & $9.1^{\mathrm{a}}$ & $8.5^{\mathrm{b}}$ & $8.3^{\mathrm{c}}$ & 0.02 & $<0.01$ \\
$\mathrm{CH}_{4} \mathrm{E}$ in Metabolizable energy (\%) & $11.2^{\mathrm{a}}$ & $10.7^{\mathrm{b}}$ & $10.3^{\mathrm{c}}$ & 0.03 & $<0.01$ \\
\hline
\end{tabular}

Means within a row with different letters differ $(p<0.05)$. ADG, average daily gain; SEM, standard error of the mean. 


\subsection{Carcass Characteristics}

Except $\mathrm{NEOH}$ and monensin addition increased the net muscle percentage to carcass weight $(\%$, Table $5 ; p=0.03)$, neither monensin nor $\mathrm{NEOH}$ addition had a significant influence on carcass characteristics of female lambs (Table $5 ; p>0.05$ ).

Table 5. Dietary supplemental effects of monensin (40 mg/kg.DM) and 2-nitroethanol (NEOH, $277 \mathrm{mg} / \mathrm{kg} \cdot \mathrm{DM})$ on carcass characteristics in female lambs.

\begin{tabular}{cccccc}
\hline \multicolumn{7}{c}{ Treatment } & & & \\
\hline Items & Control & Monensin & NEOH & SEM & $p$ Value \\
\hline Live weight slaughtered, $\mathrm{kg}$ & 43.6 & 44.2 & 42.0 & 0.65 & 0.07 \\
Carcass weight, $\mathrm{kg}$ & 21.5 & 21.1 & 20.4 & 0.49 & 0.35 \\
Net muscle weight, $\mathrm{kg}$ & 16.7 & 16.5 & 16.5 & 0.32 & 0.81 \\
Net muscle, \% carcass & $77.7^{\mathrm{b}}$ & $78.2^{\mathrm{a}}$ & $79.3^{\mathrm{a}}$ & 0.28 & 0.03 \\
Bone weight, $\mathrm{kg}$ & 3.5 & 3.6 & 3.5 & 0.07 & 0.73 \\
Meat:bone ratio & 4.8 & 4.7 & 4.7 & 0.13 & 0.61 \\
Backfat thickness, $\mathrm{mm}$ & 8.4 & 8.5 & 8.2 & 0.20 & 0.59 \\
Lion eye area, $\mathrm{cm}^{2}$ & 21.7 & 22.3 & 21.3 & 1.26 & 0.85 \\
\hline
\end{tabular}

Means within a row with different letters differ $(p<0.05)$. SEM, standard error of the mean.

\subsection{Economic Evaluation}

Dietary addition of monensin and $\mathrm{NEOH}$ reduced the feeding costs during the whole fattening period of female lambs by about CNY 2.7 and CNY 3.3, respectively. The economical evaluation of female lambs in the present study was conducted by two ways: sale benefit of live weight or sale benefit of carcass meat (Table 6). When evaluated by sale benefit of live weight: both monensin and $\mathrm{NEOH}$ were recorded the higher values in net revenue, economic feed efficiency and relative economic feed efficiency in comparison with control groups, and they ranked as $\mathrm{NEOH}>$ monensin $>$ Control. However, neither monensin nor $\mathrm{NEOH}$ had an obvious effect on the economic evaluation when evaluated by sale benefit of carcass meat.

Table 6. Economic evaluation of female lambs fed total mixed ration (TMR) supplemented with monensin (40 mg/kg.DM) and 2-nitroethanol (NEOH, $277 \mathrm{mg} / \mathrm{kg} \cdot \mathrm{DM})$.

\begin{tabular}{cccc}
\hline Items & CTR & MON & NEOH \\
\hline Feed consumption, kg/lamb & 121.5 & 117.0 & 116.0 \\
Total feed cost, CNY/lamb ${ }^{1}$ & 72.3 & 69.6 & 69.0 \\
Sale benefit of live weight ${ }^{2}$ & & & \\
Live weight gain, kg/lamb & 13.1 & 14.8 & 15.3 \\
Income of gain, CNY/lamb & 366 & 414 & 428 \\
Net revenue, CNY/lamb & 294 & 344 & 359 \\
Economic feed efficiency & 4.1 & 4.9 & 5.2 \\
Relative economic feed efficiency (\%) & 100 & 120 & 127 \\
Sale benefit of carcass meat ${ }^{3}$ & & & 16.6 \\
Net meat mass, kg/lamb & 16.4 & 16.5 & 963 \\
Income of meat, CNY/lamb & 951 & 957 & 894 \\
Net revenue, CNY/lamb & 879 & 887 & 12.9 \\
Economic feed efficiency & 12.2 & 12.7 & 106 \\
Relative economic feed efficiency (\%) & 100 & 104 & \\
\hline
\end{tabular}

1 Total feed cost calculated on a price of $0.595 \mathrm{CNY} / \mathrm{kg}$ TMR in Chinese Yuan. ${ }^{2}$ Economic benefits calculated on a market price of $28 \mathrm{CNY} / \mathrm{kg}$ live body weight in Chinese Yuan. ${ }^{3}$ Economic benefits calculated on a market price of $58 \mathrm{CNY} / \mathrm{kg}$ lamb meat in Chinese Yuan; economic efficiency was calculated as the ratio between net revenue and total feed cost; relative economic feed efficiency, economic efficiency of additive-supplemented diet relative to the control diet.

\section{Discussion}

It is well established that apparent total tract digestibility of nutrients was not influenced by monensin addition in feedlot heifers, lactating cows or growing lambs $[10,27,28]$. 
In the current study, apparent total tract digestibility of female lambs was not significantly influenced with monsensin and $\mathrm{NEOH}$ addition in the whole experiment period. Although $\mathrm{NEOH}$ is considered an efficient ruminal $\mathrm{CH}_{4}$ inhibitor in vitro $[29,30]$, little information is available regarding its nutritive and feeding value as livestock feed. Only in a recent study of Zhang et al. [18], the supplementation of NEOH had no adverse influence on the apparent digestibility of nutrient. The DMI was decreased with monensin addition in the current study. In the previous studies, Bergen and Bates suggested that DMI was declined when monensin is added in diets [31]. Dietary monensin addition often has an ability to decrease rumen motility and dilution rate of digestion of nutrients, resulting in an increase of ruminal fill and consequently a reduction of DMI. Dietary supplementation of NEOH has recently been discovered to have a negative effect on DMI in fattening lambs [18]. Furthermore, in agreement with this study, the DMI was similarly decreased with NEOH addition in the present study. As an ionophore and growth promoter, monensin has been extensively used in commercial feedlot diets to increase feed efficiency and energy utilization [32,33]. Susin et al. reported that both feed efficiency and growth rate was promoted with monensin addition in lambs [34]. Safaei et al. and Tedeschi et al. found that the supplementation of monensin in grain-based feedlot diets improved feed efficiency by reducing DMI and had no effect on ADG [35,36]. In the current study, the ADG and feed efficiency of female lambs was also improved with monensin and $\mathrm{NEOH}$ supplementation. To our knowledge, both monensin and $\mathrm{NEOH}$ has a significant antimethanogenic activity in ruminants $[10,14,17]$. The reduction in $\mathrm{CH}_{4}$ production with monensin and $\mathrm{NEOH}$ supplementation, which represented less energy loss and increasing energy metabolism, may also improve feed efficiency of female lambs. Due to the requirement of a specialized methodology [37] and expensive equipment [38] in determination of $\mathrm{CH}_{4}$ production for individual ruminants, some empirical models have been developed to estimate specific $\mathrm{CH}_{4}$ emissions from ruminant animals [24,39,40]. Based on DMI, GEI and DEI, specific models for accurate estimation of $\mathrm{CH}_{4}$ emissions $\left(\mathrm{CH}_{4} \mathrm{DMI}, \mathrm{CH}_{4} \mathrm{GEI}\right.$ and $\mathrm{CH}_{4}$ DEI $)$ from sheep were obtained from Patra et al. [26]. In the present study, both monensin and $\mathrm{NEOH}$ addition reduced $\mathrm{CH}_{4}$ production, which involved $\mathrm{CH}_{4}$ DMI, $\mathrm{CH}_{4} \mathrm{GEI}$ and $\mathrm{CH}_{4}$ DEI. Monensin is a routinely used feed additive with the potential to decrease $\mathrm{CH}_{4}$ emissions from dairy cows, beef cattle and sheep. Odongo et al. observed obvious reductions in $\mathrm{CH}_{4}$ production (6.5-12\% decrease) from dairy cows with dietary supplementation of monensin [12]. Vyas et al. evaluated the combined effects of monensin and 3-nitrooxypropanol on $\mathrm{CH}_{4}$ emissions of beef cattle, and found that the $\mathrm{CH}_{4}$ production was decreased by $26.9 \%$ when fed diet supplemented with monensin [13]. Recently, Soltan et al. also reported that monensin exhibited significant reductions in protozoal counts and $\mathrm{CH}_{4}$ emissions by $37.3 \%$ and $20.2 \%$ in growing lambs [10]. Until now, both in vitro and in vivo studies have demonstrated the antimethanogenic activity of nitrocompounds [10,14,17]. Anderson et al. [14] and Zhang et al. [41] reported that nitroethane and 2-nitroethanol were nearly equally effective in inhibiting ruminal in vitro $\mathrm{CH}_{4}$ production (up to $90 \%$ with $10 \mathrm{mM}$ ). However, in a recent study of Zhang et al., the $\mathrm{CH}_{4}$ production was reduced by up to $30 \%$ with $\mathrm{NEOH}$ addition in feedlotting lambs [18]. The antimethanogenic mechanism of $\mathrm{NEOH}$ in ruminants remains inconclusive, and further studies are needed to more fully elucidate the mode of action and toxicity of NEOH.

As reported by Eckard et al., farm managers are very interested in technologies which reduce methane production while increasing feed efficiency of bodyweight gain [42] Fortunately, female lambs in the current study fed diet with monensin and NEOH produced less $\mathrm{CH}_{4}$ emissions per $\mathrm{kg}$ ADG (L/kg ADG) by $12.7 \%$ and $17.4 \%$ in comparison with the control, and feed efficiency, measured as FCR, was also improved. This phenomenon indicating that feed energy saved form $\mathrm{CH}_{4}$ production in monensin and $\mathrm{NEOH}$-fed lambs promoted the feed efficiency and ADG in the present study. In comparison with the control, both monensin and $\mathrm{NEOH}$ decreased the percentage of $\mathrm{CH}_{4}$ energy in metabolizable energy. Therefore, the reduction in $\mathrm{CH}_{4}$ production may increase the efficiency of energy metabolism in monensin and NEOH groups. 
Monensin is widely included in feedlotting diets of lambs to improve energy utilization and consequently promote feed efficiency [33]. The beneficial influence of monensin on energy utilization may attribute to its selective inhibition of Gram-positive bacteria (such as Streptococus bovis) that altered ruminal fermentation and increased propionate production [13]. Increasing rumen propionate production has the effect of increasing the efficiency of energy metabolism. Therefore, the reduction in $\mathrm{CH}_{4}$ production represented a less energy loss, thereby may result in the increasing efficiency of energy metabolism in female lambs.

Previous studies documented that the male animals usually showed a higher growth rate and fattening performance than females [20,21]; however, the female lambs cannot be eliminated in an intensive production system in China. In the present study, the average daily gain and feed conversion rate was improved by $\mathrm{NEOH}$ and monensin, but $\mathrm{NEOH}$ in comparison with monensin presented a greater promoting effect on energy utilization in the female feedlotting lambs by inhibiting rumen methanogenesis more efficiently. The improvement of feed efficiency and animal performance in female lambs is of great important to increase the economic benefits for livestock producers.

To our knowledge, these are the first published data evaluating the effect of dietary addition of NEOH on animal carcass characteristics. The basis of body weight gain of animals usually results from the increase in mass of the principal tissues, including muscle, bones and fat. In the present study, both $\mathrm{NEOH}$ and monensin promoted the net muscle percentage to carcass weight, suggesting that the carcasses were superior in monensin and $\mathrm{NEOH}$-treated lambs than in control lambs. However, further studies are still needed in the future to evaluate the influence of monensin and NEOH addition on the carcass traits and non-carcass components. In an earlier study of Gilka et al. reported that carcass and meat quality were not affected by monensin in lambs [43]. In addition, Van Vuuren and Nel observed a lower proportion of meat but more fat in monensin-treated lambs [44]. In the present study, neither monensin nor NEOH had a negative effect on carcass characteristics of female lambs. However, the effect of dietary additive on food safety with respect to livestock product and animal health also needs future research.

Regarding economic evaluation, the economic efficiency was higher for lambs fed diets supplemented monensin and $\mathrm{NEOH}$ than control. Dietary addition of monensin and $\mathrm{NEOH}$ reduced the feeding costs during the whole fattening period of female lambs by about CNY 2.7 and CNY 3.3, respectively. However, both DMI and ADG were improved in monensin and NEOH group than in control, which will result in a higher net revenue and economic efficiency from long-term benefits.

\section{Conclusions}

In the present study, the average daily gain and feed conversion rate was promoted by $\mathrm{NEOH}$ and monensin, but $\mathrm{NEOH}$ in comparison with monensin presented a greater promoting effect on energy utilization in the female feedlotting lambs by inhibiting rumen methanogenesis more efficiently. $\mathrm{NEOH}$ and monensin increased the net muscle percentage to carcass weight, but neither NEOH nor monensin had an adverse effect on carcass characteristics. In addition, $\mathrm{NEOH}$ improved the net revenue and economic efficiency more significantly than monensin.

Author Contributions: Conceptualization, Z.-W.Z., Y.-J.Z. and H.-J.Y.; methodology, Z.-W.Z., Y.-Y.C. and L.-T.Z.; formal analysis, Z.-W.Z. and H.-J.Y.; investigation, Z.-W.Z., Y.-L.W. and Y.-X.G.; data curation, Z.-W.Z. and H.-J.Y.; writing-original draft preparation, Z.-W.Z.; writing-review and editing, Z.-W.Z., Y.-Q.L. and H.-J.Y.; project administration, H.-J.Y.; funding acquisition, H.-J.Y. All authors have read and agreed to the published version of the manuscript.

Funding: This research was funded by the National Key Research \& Development Project of China (No. 2018YFD0502104-3) and the National Natural Science Foundation of China (grant no. 31572432). 
Institutional Review Board Statement: The study was conducted according to the guidelines of the Beijing Municipal Council on Animal Care-Animal Production Ethics Committee (with protocol CAU20171014-1).

Informed Consent Statement: Not applicable.

Data Availability Statement: The data presented in this study are available on request from the corresponding author.

Conflicts of Interest: The authors declare no conflict of interest.

\section{References}

1. Mosoni, P.; Chaucheyras-Durand, F.; Béra-Maillet, C.; Forano, E. Quantification by real-time pcr of cellulolytic bacteria in the rumen of sheep after supplementation of a forage diet with readily fermentable carbohydrates: Effect of a yeast additive. J. Appl. Microbiol. 2010, 103, 2676-2685. [CrossRef] [PubMed]

2. Gobindram, M.N.N.E.; Bognanno, M.; Luciano, G.; Avondo, M.; Piccione, G.; Biondi, L. The effects of barley replacement by dehydrated citrus pulp on feed intake, performance, feeding behaviour and serum metabolic indicators in lambs. Anim. Prod. Sci. 2015, 57, 133-140. [CrossRef]

3. Armato, L.; Gianesella, M.; Fiore, E.; Arfuso, F.; Morgante, M. Effect of live yeast \& yeast cell wall saccharomyces cerevisiae diet supplementation on faeces chemical composition and growth performance in growing and finishing beef steers. Large Anim. Rev. 2016, 22, 203-210.

4. Gerber, P.J.; Hristov, A.N.; Henderson, B.; Makkar, H.; Oh, J.; Lee, C.; Meinen, R.; Montes, F.; Ott, T.; Firkins, J. Technical options for the mitigation of direct methane and nitrous oxide emissions from livestock: A review. Animal 2013, 7, 220-234. [CrossRef] [PubMed]

5. Knapp, J.R.; Laur, G.L.; Vadas, P.A.; Weiss, W.P.; Tricarico, J.M. Invited review: Enteric methane in dairy cattle production: Quantifying the opportunities and impact of reducing emissions. J. Dairy Sci. 2014, 97, 3231-3261. [CrossRef]

6. Johnson, K.A.; Johnson, D.E. Methane emissions from cattle. J. Anim. Sci. 1995, 73, 2483-2492. [CrossRef] [PubMed]

7. Hess, H.D.; Beuret, R.A.; Lotscher, M.; Hindrichsen, I.K.; Machmuller, A.; Carulla, J.E.; Lascano, C.E.; Kreuzer, M. Ruminal fermentation, methanogenesis and nitrogen utilization of sheep receiving tropical grass hay-concentrate diets offered with Sapindus saponaria fruits and Cratylia argentea foliage. Animal 2004, 79, 177-189.

8. Beauchemin, K.A.; Kreuzer, M.O.; O'Mara, F.; Mcallister, T.A. Nutritional management for enteric methane abatement: A review. Aust. J. Exp. Agric. 2008, 48, 21-27. [CrossRef]

9. Guan, H.; Wittenberg, K.M.; Ominski, K.H.; Krause, D.O. Efficacy of ionophores in cattle diets for mitigation of enteric methane. J. Anim. Sci. 2006, 84, 1896-1906. [CrossRef]

10. Soltan, Y.A.; Hashem, N.M.; Morsy, A.S.; El-Azrak, K.M.; Sallam, S.M. Comparative effects of Moringa oleifera root bark and monensin supplementations on ruminal fermentation, nutrient digestibility and growth performance of growing lambs. Anim. Feed Sci. Technol. 2018, 235, 189-201. [CrossRef]

11. Van Vugt, C. Impact of monensin on methane production and performance of cows fed forage diets. Proc. N. Z. Soc. Anim. Prod. 2005, 65, 362-366.

12. Odongo, N.; Bagg, R.; Vessie, G.; Dick, P.; Or-Rashid, M.; Hook, S.; Gray, J.; Kebreab, E.; France, J.; McBride, B. Long-term effects of feeding monensin on methane production in lactating dairy cows. J. Dairy Sci. 2007, 90, 1781-1788. [CrossRef] [PubMed]

13. Vyas, D.; Alemu, A.W.; McGinn, S.M.; Stephane, M.D.; Maik, K.; Karen, A.B. The combined effects of supplementing monensin and 3-nitrooxypropanol on methane emissions, growth rate, and feed conversion efficiency in beef cattle fed high forage and high grain diets. J. Anim. Sci. 2018, 96, 2923-2938. [CrossRef] [PubMed]

14. Anderson, R.C.; Callaway, T.R.; Kessel, J.A.S.V.; Yong, S.J.; Edrington, T.S.; Nisbet, D.J. Effect of select nitrocompounds on ruminal fermentation; an initial look at their potential to reduce economic and environmental costs associated with ruminal methanogenesis. Bioresour. Technol. 2003, 90, 59-63. [CrossRef]

15. Anderson, R.C.; Krueger, N.A.; Stanton, T.B.; Callaway, T.R.; Edrington, T.S.; Harvey, R.B.; Jung, Y.S.; Nisbet, D.J. Effects of select nitrocompounds on in vitro ruminal fermentation during conditions of limiting or excess added reductant. Bioresour. Technol. 2008, 99, 8655-8661. [CrossRef]

16. Božic, A.K.; Anderson, R.C.; Carstens, G.E.; Ricke, S.C.; Callaway, T.R.; Yokoyama, M.T.; Wang, J.K.; Nisbet, D.J. Effects of the methane-inhibitors nitrate, nitroethane, lauric acid, Lauricidin and the Hawaiian marine algae. Bioresour. Technol. 2009, 99, 4017-4025. [CrossRef]

17. Gutierrez-Bañuelos, H.; Anderson, R.C.; Carstens, G.E.; Tedeschi, L.O.; Pinchak, W.E.; Elisa, C.D.; Krueger, N.A.; Callaway, T.R.; Nisbet, D.J. Effects of nitroethane and monensin on ruminal fluid fermentation characteristics and nitrocompound-metabolizing bacterial populations. J. Agric. Food Chem. 2008, 56, 4650-4658. [CrossRef]

18. Zhang, Z.W.; Wang, Y.L.; Chen, Y.Y.; Wang, W.K.; Zhang, L.T.; Luo, H.L.; Yang, H.J. The Nitroethanol in Comparison with Monensin Exhibits Greater Feed Efficiency through Inhibiting Rumen Methanogenesis More Efficiently and Persistently in Feedlotting Lambs. Animals 2019, 9, 784. [CrossRef] 
19. Askar, A.R.; Guada, J.A.; Gonzalez, J.M.; de Vega, A.; Castrillo, C. Diet selection by growing lambs offered whole barley and a protein supplement, free choice: Effects on performance and digestion. Livest. Sci. 2006, 101, 81-93. [CrossRef]

20. Rodríguez, A.B.; Bodas, R.; Prieto, N.; Landa, R.; Mantecón, A.R.; Giráldez, F.J. Effect of sex and feeding system on feed intake, growth, and meat and carcass characteristics of fattening Assaf lambs. Livest. Sci. 2008, 116, 118-125. [CrossRef]

21. Abouheif, M.A.; Kraides, M.S.; Shatat, R.A. Effect of docking and sex of lambs on carcass characteristics of the fat tailed Najdi sheep. J. Appl. Anim. Res. 1992, 1, 91-101. [CrossRef]

22. Aregheore, E.M. Effect of sex on growth rate, voluntary intake and nutrient digestibility of West African Dwarf goats. Small Rumin. Res. 1994, 15, 217-221. [CrossRef]

23. A.O.A.C. Official Methods of Analysis, 17th ed.; Association of Official Analytical Chemists: Gaithersburg, MD, USA, 2005.

24. Van Soest, P.J.; Robertson, J.B.; Lewis, B.A. Methods for dietary fiber, neutral detergent fiber, and nonstarch polysaccharides in relation to animal nutrition. J. Dairy Sci. 1991, 74, 3583-3597. [CrossRef]

25. Peng, K.; Shirley, D.C.; Xu, Z.; Huang, Q.; Mcallister, T.A.; Chaves, A.V.; Acharya, S.; Liu, C.L.; Wang, S.X.; Wang, Y.X. Effect of purple prairie clover (dalea purpurea vent.) hay and its condensed tannins on growth performance, wool growth, nutrient digestibility, blood metabolites and ruminal fermentation in lambs fed total mixed rations. Anim. Feed Sci. Technol. 2016, 222, 100-110. [CrossRef]

26. Patra, A.K.; Lalhriatpuii, M.; Debnath, B.C. Predicting enteric methane emission in sheep using linear and non-linear statistical models from dietary variables. Anim. Prod. Sci. 2016, 56, 574-584. [CrossRef]

27. Benchaar, C. Diet supplementation with cinnamon oil, cinnamaldehyde, or monensin does not reduce enteric methane production of dairy cows: An international journal of animal bioscience. Anim. Inter. J. Anim. Biosci. 2016, 10, 418-425. [CrossRef] [PubMed]

28. Gupta, S.; Mohini, M.; Malla, B.A.; Mondal, G.; Pandita, S. Effects of monensin feeding on performance, nutrient utilisation and enteric methane production in growing buffalo heifers. Trop. Anim. Health Prod. 2019, 51, 1-8. [CrossRef]

29. Zhang, D.F.; Yang, H.J. In vitro ruminal methanogenesis of a hay-rich substrate in response to different combination supplements of nitrocompounds; pyromellitic diimide and 2-bromoethanesulphonate. Anim. Feed Sci. Technol. 2011, 163, 20-32. [CrossRef]

30. Zhang, D.F.; Yang, H.J. Combination effects of nitrocompounds, pyromellitic diimide, and 2-bromoethanesulfonate on in vitro ruminal methane production and fermentation of a grain-rich feed. J. Agric. Food Chem. 2012, 60, 364-371. [CrossRef] [PubMed]

31. Bergen, W.G.; Bates, D.B. Ionophores: Their effect on production efficiency and mode of action. J. Anim. Sci. 1984, 58, 1465-1483. [CrossRef]

32. Aderinboye, R.Y.; Onwuka, C.F.; Arigbede, O.M.; Oduguwa, O.O.; Aina, A.B. Effect of dietary monensin inclusion on performance, nutrient utilisation, rumen volatile fatty acid concentration and blood status of West African dwarf bucks fed with basal diets of forages. Trop. Anim. Health Prod. 2012, 44, 1079-1087. [CrossRef] [PubMed]

33. Chapman, C.E.; Chester-Jones, H.; Ziegler, D.; Clapper, J.A.; Erickson, P.S. Effects of cinnamaldehyde or monensin on performance of weaned Holstein dairy heifers. J. Dairy Sci. 2017, 100, 1712-1719. [CrossRef] [PubMed]

34. Susin, I.; Mendes, C.Q.; Pires, A.V.; Packer, I.U. Monensin or decoquinate in high concentrate diets fed to Santa Ines lambs. J. Dairy Sci. 2004, 87, 40.

35. Safaei, K.; Tahmasbi, A.M.; Moghaddam, G. Effects of high concentrate:forage ratio diets containing monensin on the management of ruminal acidosis in Gezhel lambs. Small Rumin. Res. 2014, 121, 183-187. [CrossRef]

36. Tedeschi, L.O.; Fox, D.G.; Tylutki, T.P. Potential environmental benefits of ionophores in ruminant diets. J. Environ. Qual. 2003, 32, 1591-1602. [CrossRef] [PubMed]

37. Kebreab, E.; Clark, K.; Wagner-Riddle, C.; France, J. Methane and nitrous oxide emissions from Canadian animal agriculture: A review. Can. J. Anim. Sci. 2006, 86, 135-158. [CrossRef]

38. Hammond, K.J.; Crompton, L.A.; Bannink, A.; Dijkstra, J.; Yáñez-Ruiz, D.R.; O’Kiely, P.; Kebreab, E.; Eugène, M.A.; Yu, Z.; Shingfield, K.J.; et al. Review of current in vivo measurement techniques for quantifying enteric methane emission from ruminants. Anim. Feed Sci. Technol. 2016, 219, 13-30. [CrossRef]

39. Ramin, M.; Huhtanen, P. Development of equations for predicting methane emissions from ruminants. J. Dairy Sci. 2013, 96, 2476-2493. [CrossRef]

40. Cottle, D.J.; Eckard, R.J. Global beef cattle methane emissions: Yield prediction by cluster and meta-analyses. Anim. Prod. Sci. 2018, 58, 2167-2177. [CrossRef]

41. Zhang, Z.W.; Wang, Y.L.; Wang, W.K.; Li, Y.H.; Cao, Z.J.; Li, S.L.; Yang, H.J. The inhibitory action mode of nitrocompounds on in vitro rumen methanogenesis: A comparison of nitroethane, 2-nitroethanl and 2-nitro-1-propanol. J. Agric. Sci. 2019, 157, 471-479. [CrossRef]

42. Eckard, R.J.; Grainger, C.; De Klein, C.A.M. Options for the abatement of methane and nitrous oxide from ruminant production. Livest. Sci. 2010, 130, 47-56. [CrossRef]

43. Gilka, J.; Jelínek, P.; Janková, B.; Krejči, P.; Habrda, J. Carcass traits and meat quality of male lambs fed monensin or lasalocid. Meat Sci. 1989, 25, 265-272. [CrossRef]

44. Van Vuuren, B.G.J.; Nel, J.W. The effect of monensin on the efficiency of feed conversion, carcass traits and the occurrence of coccidiosis in lambs. S. Afr. J. Anim. Sci. 1983, 3, 87-90. 